\title{
Globalization and knowledge spillover: International direct investment, exports and patents
}

\author{
C.-L. Chang ${ }^{a}$, S.-P. Chen ${ }^{b}$ and M. McAleer ${ }^{c}$ \\ ${ }^{a}$ Department of Applied Economics and Department of Finance, National Chung Hsing University, Taichung, \\ Taiwan \\ ${ }^{b}$ Department of Applied Economics, National Chung Hsing University, Taiwan \\ ${ }^{c}$ Econometric Institute, Erasmus School of Economics, Erasmus University Rotterdam, and Tinbergen \\ Institute, The Netherlands \\ Email: changchialin@nchu.edu.tw
}

\begin{abstract}
This paper examines the impact of the three main channels of international trade on domestic innovation, namely outward direct investment, inward direct investment (IDI) and exports. The number of Triadic patents serves as a proxy for innovation. The data set contains 37 countries that are considered to be highly competitive in the world market, covering the period 1994 to 2005 . The empirical results show that increased exports and outward direct investment are able to stimulate an increase in patent output. In contrast, IDI exhibits a negative relationship with domestic patents. The paper shows that the impact of IDI on domestic innovation is characterized by two forces, and the positive effect of cross-border mergers and acquisitions by foreigners is less than the negative effect of the remaining IDI.
\end{abstract}

Keywords: International direct investment, Export, Triadic Patent, Outward Direct Investment, Inward Direct Investment, R\&D, negative binomial model. 


\section{INTRODUCTION}

"Globalization" means different things in different contexts. From an economic perspective, it refers to the cross-border movements of goods, funds, personnel and information. The more easily do such movements take place, the higher is the degree of globalization. In this context, the movement of goods refers to trade, while movements of funds refer to international direct investment (Liu et al., 2005). Furthermore, based on the direction of the flow of capital, foreign direct investment can be broken down into outward direct investment (hereafter ODI) and inward direct investment (hereafter IDI).

According to the World Investment Report by the United Nations and the World Development Indicators by the World Bank, in 2008 the amounts of ODI and exports for the world as a whole over the years have generally exhibited an upward trend. They have both accounted for an important share of GDP, as shown in Figures 1, 2 and 3, have played an essential role in the process of globalization, and have been regarded as the main channels for technology spillover (Branstetter, 2006; Liu \& Zou, 2008). Furthermore, according to endogenous growth theory, technological innovation is important to the "sustained" growth of an economy (Romer, 1986; Lucas, 1988). The main reasons for the economic growth of the late-industrializing economies have been the acquisition of knowledge and intelligence, technological innovation and human capital accumulation (Bassanini and Scarpetta, 2002; Hu \& Mathews, 2005; Mueller, 2006).

From the above, it can be seen that countries that frequently engage in ODI also attract IDI and promote export activities. Such behavior raises the issue as to why countries wish to engage in such activities. For this reason, we propose the following questions: are ODI, IDI and exports capable of enhancing a country's innovation and technological depth? Conversely, it needs to be asked whether these activities can lower a country's willingness to engage in innovation activities, and over the long term cause that country to lack competitiveness in international markets, with the result that the economy's growth can not be sustained, so that the country falls into recession.

This paper examines, within the context of globalization, the impact of the three main channels of international trade, namely ODI, IDI and exports, on domestic innovation, where the number of patents serves as a proxy for innovation. By examining the impact between countries, within the context of globalization, of ODI, IDI and exports on patents, it is hoped that the results of this paper can serve as a reference for public and private policy, and that appropriate international trade policies may be formulated to increase a country's innovation activities, upgrade its industrial technology, and ultimately promote economic sustainability and stable growth.

\section{EXPORTS, INTERNATIONAL DIRECT INVESTMENT, AND INNOVTION}

Traditional economic theory on the relationship between innovation and exports largely focuses on the topic of whether innovation influences exports. For example, the technological gap theory (Posner, 1961) and the life-cycle theory (Vernon, 1966) both argue that innovation will give manufacturers a greater comparative advantage, so that they will become net exporters. Moreover, in early studies, the focus was on whether a country that is engaged in innovation activities can provide a boost to exports (Roper \& Love, 2002; Gourlay \& Seaton, 2004; Yang et al., 2004; Gourlay et al., 2005; Roper et al., 2006; Tomiura, 2007). In contrast, the impact of exports on innovation has not yet led to consistent results (Keller, 2009). In recent years, studies on these two issues have focused mainly on discussing the impact of exports on innovation. For example, Lin \& Yeh (2005) found that the exports of Taiwan's electronics industry exhibited a significantly positive relationship with that industry's $\mathrm{R} \& \mathrm{D}$, but that such a relationship only existed in the case of manufacturers engaged in foreign direct investment. For South Korean manufacturers as an example, Han \& Lee (2007) used the number of patents approved by the U.S. Patent Office and the South Korean Intellectual Property Office (KIPO) as the explained variables to examine the impact of the export ratio on innovation. Their results indicated that the proportion of exports only exhibited a significant and positive relationship in regard to those patents approved by the U.S. It was argued that this difference arose because the different strategies adopted by manufacturers in applying for patents either at home or abroad.

The discussion to date has not taken into consideration the possibility that the impact of exports on innovation was subject to a time lag. In fact, the impact of exports on innovation is likely to have a deferred effect. For example, Salomon \& Shaver (2005) discovered that for Spanish manufacturers there existed a significant and positive relationship between the export behavior of Spanish manufacturers, with a time lag of one or two periods, and the number of products innovated in the domestic economy, as well as the number of patent applications. Through exports, it was possible to acquire knowledge that was lacking in the domestic 
market, and thereby to promote innovation. In other words, the effect of learning by exporting was found to exist. In order to verify this learning effect, Girma et al. (2008) analyzed manufacturers in the U.K. and Ireland. Their results showed that Irish exports were able to increase innovation activities with a time lag of one period, whereas in the U.K. there was no compelling evidence to show that exports could increase innovation activities. The authors concluded that this difference was due to the domestic markets, the sizes of these two countries, and the destinations of their exports not being the same.

Based on Salvatore's (2007) definition, international direct investment refers to real investment engaged in abroad, and includes the acquisition and control of factories, capital goods, land, inventory and management. It frequently involves either the setting up of overseas subsidiaries or purchasing large quantities of shares in order to obtain the right to operate. According to the direction in which the funds for investment flow, a distinction may be made between ODI and IDI. Two main types of result may be inferred from past empirical studies: in terms of its impact on innovation, international direct investment has (1) positive spillover effects, and (2) negative or uncertain spillover effects.

The positive spillover effects refer to the discovery of knowledge spillovers, such as technology or management, when engaging in IDI or ODI. This leads to an increase in innovation activities in the host country and/or the home country. For example, Lin \& Yeh (2005) interpret IDI and R\&D as being mutually dependent, so that if the quantity of input of one increases, the amount of expenditure on the other is also increased. Blind \& Jungmittag (2004) argued that externally-induced competition has a training effect on the host country's domestic market which, in turn, has a positive effect on the host country's innovation activities. However, Lin et al. (2009) adopted a quite different approach to analyzing ODI. They argued that ODI benefits the home country's innovation. Branstetter (2006) also advanced a similar view, and proceeded to consider that international direct investment embodied a feedback effect, so that ODI not only caused the innovative behavior of the host country to increase, but also led to a positive effect on innovation activities in the home country.

The negative spillover effect refers to inflows of foreign capital which result in the host country becoming excessively dependent on technology, thereby leading to a reduction in innovation activities (Kumar, 1987). However, the uncertain spillover effect refers to foreign capital impacting the host country's innovation activities both positively and negatively. First, different measurement indicators of IDI are used simultaneously, as in Girma et al. (2009), who used the proportion of foreign investment and the amount of foreign investment sold domestically as the IDI indicator. The empirical evidence showed that the proportion of foreign investment has a positive and significant effect on product innovation, while the amount of foreign investment is characterized by a significant and negative relationship with product innovation.

Second, different studies have focused on different industries. For instance, Deolalikar \& Evenson (1989) sought to estimate the patent demand function for India. Their empirical results indicated that the higher the proportion of foreign investment in the chemical industry, the smaller the number of patents. In contrast, in the light engineering and other engineering industries, IDI was found to be positively related to patents.

Finally, various results have also been obtained when international direct investment is decomposed into ODI and IDI. For instance, Pottelsberghe \& Lichtenberg (2001) used a sample of 13 OECD countries to examine whether FDI led to a technology transfer effect, and concluded that transfers of technology across borders as part of FDI should not be considered in one direction only. Thus, they decomposed FDI into ODI and IDI in order to view capital flows as moving in two directions. Their empirical evidence showed that ODI is a technology spillover channel that has both a significant and positive effect on the domestic country's total factor productivity. In contrast, IDI did not help to improve the technology of the host country, and even adversely affected it. The reason for this was that IDI had a tendency to acquire technology from the host country, and then to give this technology, which it did not disseminate in its own country (the home country), to another country (the host country).

In addition, as the proportion of cross-border mergers and acquisitions (hereafter cross-border M\&As) in international direct investment has been increasing annually (UNCTAD, 2007), in empirical research the topic of IDI has also been examined together with that of cross-border M\&As. For example, Liu \& Zou (2008) found that the significant and positive relationship between cross-border M\&As activities in China's high-technology industry and innovation only existed among different industries, and that within a particular industry the relationship was positive but not significant. The reason for this was that mergers and acquisitions activities may increase the degree of industrial concentration and monopoly power, so that industries within the same domestic sector will be characterized by relatively little innovative behavior.

Using a sample of 14 OECD member states, Bertrand \& Zuniga (2006) examined the relationship between cross-border M\&As by foreigners and $\mathrm{R} \& \mathrm{D}$, and their empirical results showed that the overall relationship 
was positive but not significant. By focusing on the industries' technology intensity, the relationships between these mergers and acquisitions activities and R\&D for high, medium and low levels of technology were found to be negative and not significant, significant and positive, and positive and not significant, respectively. Thus, it can be seen that the significant and positive relationship between cross-border M\&As by foreigners and innovation exists only in the local context.

\section{DATA}

This paper uses panel data for 37 countries covering the period 1994 to 2005 . There are three criteria for selecting the sample, as follows: (1) globalization, (2) OECD member states, and (3) upper-middle or high income countries. The reason for using these three criteria is that the emphasis in this paper is on globalization, so that the most important economies on the five continents, namely Europe, Asia, America, Oceania and Africa, are included in the sample. Second, the motivation for including the OECD countries in the sample is that more than $90 \%$ of the world's foreign direct investment originates in OECD countries $(\mathrm{Ou}$ Yang \& Hwang, 2006), so that the vast majority of OECD countries are engaged in cross-border direct investment activities. Finally, the reason for selecting upper-middle or high income countries is that when relatively high income countries are compared with low income countries, the higher income countries will tend to engage in R\&D activities, and will attach greater importance to patents, which are the embodiment of intellectual property rights.

This paper uses patents as a proxy for innovation. In selecting the number of patents, previous studies have frequently used the number of patent applications submitted to a specific patent office as the innovation index (Branstetter, 2006; Deolalikar \& Evenson, 1989). Alternatively, they have used the "corresponding" numbers of patents applied for to the patent offices of two countries to represent this number, and thereby facilitate a comparison (Han \& Lee, 2007). In this paper, it is argued that comparing the differences in innovation output between countries will lead to bias, due to the host country's home advantage, if only the applications for patents to a single patent office are used. When an inventor applies for a patent, as compared with applying to a patent office in another country, they are more likely to prefer to apply to their own country's patent office for a patent. For this reason, we use a triadic patent that is based on "simultaneous" applications for approval to patent offices in Europe, USA and Japan as our indicator. In this way, we can reduce the bias that is generated due to the host country's advantage.

In addition, as a patent is the outcome of innovation, if we can presume that a higher economic value of an innovation is implied by a triadic patent, the greater will the patent be able to reflect economic growth. In addition, this paper uses patents applied for in one direction to the European patent office, that is, unilateral patents, so that we can further compare whether differences in the numbers of patents are significant in relation to the coefficients of the explanatory variables.

Exports and international direct investment constitute the main channel of technology spillover among countries (Branstetter, 2006; Liu \& Zou, 2008). Of these, international direct investment is bidirectional, and can be divided into ODI and IDI (Pottelsberghe \& Lichtenberg, 2001). Meanwhile, based on the definition provided in the the United Nations' World Investment Report for 2008, Foreign Direct Investment comprises three parts, namely, equity capital, reinvested earnings, and intra-company loans. Thus, we further decompose IDI into two parts, namely cross-border M\&As by foreigners, and other direct investment.

In addition, $R \& D$ activities require inputs over a long period of time to produce results, the inputs in the current period will be separated from the benefits not yet seen by a time lag extending to future periods (Tsou \& Liu, 1997). For this reason, the lag of R\&D is taken into consideration (Han \& Lee, 2007). As the sample includes data for 37 countries, to remove differences in the amounts expended on R\&D varying from country to country, all of the explanatory variables are divided by their own-country GDP.

Using the descriptive statistics, which are not reported, three phenomena may be observed. First, regardless of whether the triadic patent (TRI_PATENT) or the unilateral patent (EPO_PATENT) is used, the respective standard deviations are both twice as large as their means. From this, we see that the patent information is characterized by over-dispersion. Second, by adding the means of total exports (EXP) and ODI, their combined share of GDP exceeds 40 percent $(0.3896+0.0254=0.415)$. In other words, exports and ODI together account for a high proportion of international trade. Third, with cross-border M\&As by foreigners (M \& A SALE) accounting for more than one-half of IDI $(0.0176 / 0.0325=0.54)$, it is clear that cross-border M\&As are the main component of international direct investment. 


\section{MODELS}

\subsection{Negative Binomial Model}

As a patent is a non-negative discrete variable, this paper uses the count data model. The two types of count data model commonly used are the Poisson model and the Negative binomial model. The Poisson model's probability density function is given in equation (1), where $y_{i t}$ is the number of patents in country $i$ in year $t$, and $\lambda_{i t}$ is the average number of patents in country $i$ in year $t$, namely the unit frequency of patent applications. In this model, the mean and variance are equal, as shown in equation (2). However, in empirical research patent data are often characterized by over dispersion (Aggarwal, 2004), that is, the variance is greater than the mean. Thus, the Poisson model may be inappropriate, so that the negative binomial model is commonly used to resolve the shortcomings of the Poisson model:

$$
\begin{aligned}
& \operatorname{Prol}\left(y_{i t}\right)=\frac{e^{-\lambda_{i t}} \lambda_{i t} y_{i t}}{y_{i t} !} \quad y_{i t}=0,1,2, \ldots, n \\
& E\left(y_{i t}\right)=\lambda_{i t}, \quad \operatorname{Var}\left(y_{i t}\right)=\lambda_{i t}
\end{aligned}
$$

According to Hausman et al. (1984), the negative binomial model has an individual and unobserved effect, which generalizes the Poisson model. It assumes that the Poisson model parameter, $\lambda_{\mathrm{it}}$, conforms to a Gamma $\left(\gamma_{\mathrm{it}}, \delta\right)$ distribution, where $\delta$ does not change across countries or over time (see Hausman et al., 1984).

The negative binomial model relaxes the assumption in the Poisson model that the mean and variance are equal, so that it allows the number of patents to be characterized by over dispersion, as in (3):

$$
\begin{aligned}
& \operatorname{Var}\left(y_{i t}\right)=\frac{\gamma_{i t} \cdot(1+\delta)}{\delta^{2}} \\
& E\left(y_{i t}\right)=\frac{\gamma_{i t}}{\delta} \\
& \frac{\operatorname{Var}\left(y_{i t}\right)}{E\left(y_{i t}\right)}=\frac{(1+\delta)}{\delta}>1
\end{aligned}
$$

As this paper uses panel data, we can use the fixed effects and random effects models, each of which is explained below.

\subsection{Fixed Effects Negative Binomial Model}

First, we configure the model parameters, $\gamma_{i t}$ and $\delta_{i}$, as shown in equations (4)-(7) below:

$$
\begin{aligned}
\lambda_{i t} & =\gamma_{i t} \cdot \alpha_{i}=e^{\beta \cdot X_{i t}} \cdot e^{\mu_{i}} \\
\delta_{i} & =\frac{\phi_{i}}{e^{\mu_{i}}} \\
\gamma_{i t} & =E\left(y_{i t}\right)=e^{\beta \cdot X_{i t}} \\
\alpha_{i} & =e^{\mu_{i}}
\end{aligned}
$$

where $y_{i t}$ is the number of patents in country $i$ in year $t, \gamma_{i t}$ is the expected value of $y_{i t}, X_{i t}$ denotes the explanatory variables, $\beta$ is a parameter to be estimated, and $\alpha_{i}$ is the fixed effect of an individual country $i$ that does not change over time.

Under the conditions of the sum of the patents, $\sum_{t} y_{i t}$, the conditional probability density function of $y_{i} \equiv\left(y_{i 1}, \ldots, y_{i t}\right)$ is given in equation (8). From equation (9), it can be seen that the variance is greater than the mean, so that this model allows the explained variable to be characterized by over dispersion: 
Chang et al., Globalization and knowledge spillover: International direct investment, exports and patents

$$
\begin{aligned}
& \operatorname{Pr}\left(y_{i} \mid \sum_{t} y_{i t}\right)=\frac{\Gamma\left(\sum_{t} \gamma_{i t}\right) \Gamma\left(\sum_{t} y_{i t}+1\right)}{\Gamma\left(\sum_{t} \gamma_{i t}+\sum_{t} y_{i t}\right)} \cdot\left[\prod_{t} \frac{\Gamma\left(\gamma_{i t}+y_{i t}\right)}{\Gamma\left(\gamma_{i t}\right) \Gamma\left(y_{i t}+1\right)}\right] \\
& \frac{\operatorname{Var}\left(y_{i t}\right)}{E\left(y_{i t}\right)}=\frac{e^{\mu_{i}}+\phi_{i}}{\phi_{i}}>1 \Rightarrow \operatorname{Var}\left(y_{i t}\right)>E\left(y_{i t}\right)
\end{aligned}
$$

Finally, we can derive the likelihood function, as shown in equation (10). After $\gamma_{i t}=e^{\beta \cdot X_{i t}}$ is substituted, maximum likelihood estimation can be used to obtain estimates of the parameters:

$$
\ln L=\sum_{i}\left[\begin{array}{l}
\ln \Gamma\left(\sum_{t} \gamma_{i t}\right)+\ln \Gamma\left(\sum_{t} y_{i t}+1\right)-\Gamma\left(\sum_{t} \gamma_{i t}+\sum_{t} y_{i t}\right) \\
+\sum_{t} \ln \Gamma\left(\gamma_{i t}+y_{i t}\right)-\ln \Gamma\left(y_{i t}\right)-\ln \Gamma\left(y_{i t}+1\right)
\end{array}\right]
$$

\subsection{Random Effects Negative Binomial Model}

The steps for inferring the random effects model are essentially the same as those for the fixed effects model discussed above. The difference from the fixed effects model is that the random effects model assumes that $\delta_{i}$ is randomly distributed, in which case the joint probability density function for $y_{i} \equiv\left(y_{i 1}, \ldots, y_{i t}\right)$ and $\delta_{i}$ is given in equation (11) below:

$$
\operatorname{Pr}\left(y_{i}, \delta_{i}\right)=\operatorname{Pr}\left(y_{i}\right) \cdot g\left(\delta_{i}\right)
$$

In order to obtain the probability density function of $y_{i}$, it is necessary to use integration to remove $\delta_{i}$ from the joint probability density function. For this reason, it is necessary to select an appropriate distribution for $\delta_{i}$, as shown in equation (12), where $z_{i}$ conforms to a Beta $(a, b)$ distribution. The probability density function is given in equation (13):

$$
\begin{aligned}
& z_{i}=\frac{\delta_{i}}{1+\delta_{i}}=\frac{1}{1+e^{\mu_{i}} / \phi_{i}} \\
& f\left(z_{i}\right)=[B(a, b)]^{-1} z^{a-1}(1-z)^{b-1}
\end{aligned}
$$

Through substitution of the above conditions and using integration, we can obtain the probability density function of $y_{i}$, as shown in equation (14), and obtain its likelihood function, as in equation (15). After $\gamma_{i t}=e^{\beta \cdot X_{i t}}$ is substituted, by using maximum likelihood estimation, we can obtain the estimates of the parameters:

$$
\begin{gathered}
\operatorname{Pr}\left(y_{i}\right)=\int_{0}^{1} \prod_{t=1}^{T}\left[\frac{\Gamma\left(\gamma_{i t}+y_{i t}\right)}{\Gamma\left(\gamma_{i t}\right) \Gamma\left(y_{i t}+1\right)} z_{i t}^{\gamma_{i t}}\left(1-z_{i}\right)^{y_{i t}}\right] f\left(z_{i}\right) d z_{i} \\
=\frac{\Gamma(a+b) \cdot \Gamma\left(a+\sum \gamma_{i t}\right) \cdot \Gamma\left(b+\sum y_{i t}\right) \cdot\left[\prod_{t} \frac{I\left(\gamma_{i t}+y_{i t}\right)}{\Gamma\left(y_{i t}\right) \Gamma\left(y_{i t}+1\right)}\right] \cdot \Gamma(b) \cdot \Gamma\left(a+b+\sum \gamma_{i t}+\sum y_{i t}\right)}{\ln L}=\sum_{i}\left\{-\ln \Gamma\left(a+b+\sum \gamma_{i t}+\sum y_{i t}\right)+\sum_{t}\left[\ln \Gamma\left(y_{i t}+y_{i t}\right)-\ln \Gamma\left(\gamma_{i t}\right)-\ln \Gamma\left(y_{i t}+1\right)\right\}\right\}
\end{gathered}
$$

The basic model in this paper examines the impact of exports, ODI, IDI and R\&D expenditure, using a time lag of one period on triadic patents, with the empirical model given in equation (16). In (16), $\gamma_{i t}$ represents the expected value of the triadic patent, $E X P_{i t}$ denotes exports, $O D I_{i t}$ is outward direct investment, $I D I_{i t}$ is inward direct investment, $L 1 \_G E R D_{i t}$ is domestic R\&D expenditure, with a time lag of one period, $\varepsilon_{i t}$ is the error term, and $\beta_{1}, \beta_{2}, \beta_{3}$ and $\bar{\beta}_{6}$ are the parameters associated with the explanatory variables:

$$
\begin{gathered}
\gamma_{i t}=\exp \left(\beta_{1} \cdot E X P_{i t}+\beta_{2} \cdot O D I_{i t}+\beta_{3} \cdot I D I_{i t}+\right. \\
\left.\beta_{6} \cdot L 1_{-} G E R D_{t}+\varepsilon_{i t}\right)
\end{gathered}
$$


As the proportion of cross-border M\&As in international direct investment increases annually (see UNCTAD, 2007), we decompose inward direct investment (IDI) into cross-border M\&As by foreigners and other direct investment, with a view to examining the impact of these two forces on triadic patents. The empirical model is given in equation (17), where MA_SALE $E_{i t}$ denotes cross-border M\&As by foreigners, PRIVATE $E_{i t}$ is other direct investment, $\gamma_{i t}, E X P_{i t}, O D I_{i t}, L 1_{-} G E R D_{i t}$ and $\varepsilon_{i t}$ is as defined above, and $\beta_{1}, \beta_{2}, \beta_{3}, \beta_{4}, \beta_{5}$ and $\beta_{6}$ are the parameters:

$\gamma_{i t}=\exp \left(\beta_{1} \cdot E X P_{i t}+\beta_{2} \cdot O D I_{i t}+\right.$

$\beta_{4} \cdot M A_{-} S A L E_{i t}+\beta_{5} \cdot P R I V A T E_{i t}+$

$\left.\beta_{6} \cdot L 1_{-} G E R D_{i t}+\varepsilon_{i t}\right)$

In order to make the empirical results reflect more accurately the source of most R\&D expenditure, we change the data on $R \& D$ expenditure from total domestic $R \& D$ expenditure (GERD) to R\&D expenditure for the domestic business sector (BERD). Finally, the patent data are changed from triadic patents to unilateral patents.

\section{EMPIRICAL RESULTS}

The model used in the empirical analysis examines the impact of four variables, namely exports, ODI, IDI and $R \& D$ expenditure on patents. In order to maintain consistency, it is necessary to determine the number of periods for which R\&D expenditure is deferred in order to establish the basic model. In order to enhance efficiency in estimation, we use bootstrapping methods to estimate the variances. Tables 5-8 report the t-values both with and without bootstrapping.

Table 1 reports the results of determining the number of periods by which the R\&D expenditure should be deferred using the negative binomial model based on both fixed and random effects. The empirical results indicate that the influence of R\&D expenditure deferred one period improves explanatory power. The finding that the impact of the R\&D input on patents has a one-period lag effect is consistent with that of Tsou \& Liu (1997). For this reason, in the subsequent discussion, R\&D expenditure deferred one period (L1_GERD) will serve as the R\&D expenditure variable, such that columns (2) and (6) in Table 1 will be the basic model.

In Table 2, we test the model using the Hausman test, with the null hypothesis as the random effects model, and the alternative hypothesis as the fixed effects model. As the test does not reject the null hypothesis, the subsequent analysis is explained using the random effects model. From the basic model, we can draw the following four conclusions:

(i) Exports (EXP) exhibit a significant positive relationship with patents at the $1 \%$ level. This result explains the strong competition facing world markets. For a country's exporters to gain a foothold in international markets, it is necessary to improve the quality of their exports. For this reason, they have an incentive to engage in $\mathrm{R} \& \mathrm{D}$, and to apply for patents to protect their innovations, thereby enhancing their export competitiveness.

(ii) Outward direct investment (ODI) also exhibits a significant and positive relationship with patents at the $1 \%$ level, which indicates that a country that is engaged in ODI is able to access knowledge, technology and other additional products from the host country, import this to the home country, to engage in innovative R\&D to enhance the level of technology, and in turn apply for a patent. In contrast, inward direct investment (IDI) by foreigners exhibits a negative, but insignificant, relationship with the home country's patents. This indicates that inflows of foreign investment not only do not positively benefit the innovation in the home country, but negatively impacts it instead. The results of the impact of the two-way direct investment (ODI and IDI) effect on innovation are consistent with the conclusion reached by Pottelsberghe \& Lichtenberg (2001).

(iii) Domestic R\&D expenditure with a lag of one period (L1_GERD) exhibits a positive relationship with the patent at the $10 \%$ level. The results suggest that further discussion on this issue is required, as R\&D expenditure and patents are innovative inputs and outputs, and hence should be characterized by a highly significant relationship. For this reason, we discuss this issue at greater length below.

(iv) By comparing three behavioural coefficients, namely exports, ODI and R\&D expenditure, that can be determined in the home country, it is found that the impacts of all three coefficients on patents, from the largest to the smallest, are as follows: R\&D expenditure (10.364), exports (1.476), and ODI (1.411).

Table 3 presents the empirical results for equation (22), wherein IDI is decomposed into cross-border M\&As, and other direct investment by foreigners, and the impact of each on patents is then tested. The empirical 
results are presented in Table 3, and there are two conclusions:

(v) the relationships and significance between exports, ODI, R\&D expenditure with a lag of one period and patents are all consistent with the results of the basic model;

(vi) cross-border M\&As by foreigners exhibit a positive, but not significant, relationship with the patents.

This result is consistent with that of Bertrand \& Zuniga (2006), who use 14 OECD member countries as their sample. Other direct investment has a negative relationship with patents at the $10 \%$ level. From these two impacts on patents, one negative and one positive, we can indirectly explain why IDI exhibits a negative but insignificant relationship on patents. The reason is that the negative effect of other direct investment on patents is stronger than the positive effect on patents of cross-border M\&As by foreigners. In other words, inflows of foreign capital, in general, are of little or no benefit to domestic innovation. However, if these inflows are decomposed into two parts, namely, cross-border M\&As by foreigners and other direct investment, then it is not the case that they have no effect on domestic innovation, but rather that there is only a limited positive effect on innovation.

The results of the basic model show that $R \& D$ expenditure does not have a significant impact on patents, and so this section examines the innovation input and output sides, as represented by R\&D expenditure and patent data. First, we change the R\&D expenditure data from the overall domestic R\&D expenditure (GERD) used in the basic model into the domestic business sector R\&D expenditure (BERD), and examine whether this replacement is able to change the significance of R\&D expenditure on patents. By comparing columns (2) and (4) in Table 4, it can be seen that, in the random effects model, R\&D expenditure with a lag of one period is still not significant for patents, but the estimated coefficients are significantly different from each other.

Thus, it can be seen that the differences in the patent data differ markedly in relation to the significance of the coefficients of the explanatory variables. In other words, when comparing the results of innovation across countries, the selection of patents is important. Taking the present paper as an example, because the sample encompasses five continents, if unilateral patents are used as the innovation indicator, such a choice is clearly not objective and easily leads to bias. Thus, it is suggested that using the triadic patent as a proxy for innovation is more appropriate.

The empirical results above have shown that inflows of foreign capital are of little or no benefit to domestic innovation, but instead lead to a negative impact. In contrast, by engaging in autonomous behaviour through exports, ODI and R\&D, it is possible to promote innovation activities domestically. In order that excessive reliance and expectations are not placed on inflows of foreign capital, the best policy for the promotion of innovation is to maintain a firm grasp on the domestic country's affairs. It is only in this way that the level of technology can be enhanced, technical standards upgraded, and ultimately the promotion of economic growth sustained.

The reason why inventors apply for patents is to protect their innovations. However, behind the results of innovation, there is usually a perceived economic value. The higher is this economic value, the greater is the incentive for these inventors to apply simultaneously for patents in different countries. From the definitions of the variables described above, triadic patents represent simultaneous applications for patents in Europe, USA and Japan, while unilateral patents refer to applications for patents made to the European patent office. For this reason, it can be assumed that triadic patents are superior to unilateral patents in terms of representing economic benefits.

\section{REFERENCES}

Aggarwal, A. (2004). Macro Economic Determinants of Antidumping: A Comparative Analysis of Developed and Developing Countries, World Development, 32, pp. 1043-1057.

Bassanini, A., and Scarpetta, S. (2002). Does human capital matter for growth in OECD countries? A pooled mean-group approach, Economics Letters, 74, pp.399-405.

Bertrand, O., and Zuniga, P. (2006). R\&D and M\&A: Are Cross-border M\&A Different? An Investigation on OECD Countries, International Journal of Industrial Organization, 24, pp. 401-423.

Blind, K., and Jungmittag, A. (2004). Foreign Direct Investment, Imports and Innovations in the Service Industry. Review of Industrial Organization, 25, pp. 205-227.

Branstetter, L. (2006). Is Foreign Direct Investment a Channel of Knowledge Spillovers? Evidence from Japan's FDI in the United States. Journal of International Economics, 68, pp. 325-344.

Deolalikar, A.B., and Evenson, R.E. (1989). Technology Production and Technology Purchase in Indian Industry: An Econometric Analysis. The Review of Economics and Statistics, 71, pp. 687-692.

European Patent Organisation (2010). accessed at http://www.epo.org/about-us/epo.html. 
Chang et al., Globalization and knowledge spillover: International direct investment, exports and patents

Girma, S., Gong, Y., and Görg, H. (2009). What Determines Innovation Activity in Chinese State-owned Enterprises? The Role of Foreign Direct Investment. World Development, 37, pp. 866-873.

Girma, S., Görg, H., and Hanley, A. (2008). R\&D and Exporting - A Comparison of British and Irish Firms. Review of World Economics, 144, pp. 750-771.

Gourlay, A., and Seaton, J. (2004). Explaining the Decision to Export: Evidence from UK Firms. Applied Economics Letters, 11, pp. 153-158.

Gourlay, A., Seaton, J. and Suppakitjarak, J. (2005). The Determinants of Export Behaviour in UK Service Firms. The Service Industries Journal, 25, pp. 879-889.

Han, Y.J., and Lee, W.Y. (2007). The Effects of the Characteristics of Korean Firms on the Patent Production Function. Economics of Innovation and New Technology, 16, pp. 293-301.

Hausman, J.A., Hall, B.H., and Griliches, Z. (1984). Econometric Models for Count Data with an Application to the Patents-R\&D Relationship. Econometrica, 52, pp. 909-938.

Hu, M. C., and Mathews, J.A. (2005). National Innovative Capacity in East Asia. Research Policy, 34, pp. 1322-1349.

Keller, W. (2009). International Trade, Foreign Direct Investment, and Technology Spillovers, NBER Working Paper 15422. Cambridge, MA: National Bureau of Economic Research.

Kumar, N. (1987). Technology Imports and Local Research and Development in Indian Manufacturing. The Developing Economies, 25, pp. 220-233.

Lin, H.L., and Yeh, R.S. (2005). The Interdependence between FDI and R\&D: An Application of an Endogenous Switching Model to Taiwan's Electronics Industry. Applied Economics, 37, pp. 1789-1799.

Lin, H.L., Yeh, R.S., and Chung, C.F. (2009). The Effect of Outward Investment to China on Domestic R\&D: A Two-hurdle Model with Endogenous ODI. Applied Economics, 41, pp. 1191-1198.

Liu, B.-J., Chen, T.-J., and Weng, Y.-H. (2005). Trade Theory and Policy. Taiwan: Yeh-Yeh Book Gallery. (in Chinese)

Liu, X., and Zou, H. (2008). The Impact of Greenfield FDI and Mergers and Acquisitions on Innovation in Chinese High-tech Industries. Journal of World Business, 43, pp. 352-364.

Lucas, R.E. (1988). On the Mechanics of Economic Development, Journal of Monetary Economics, 22, 3-42.

Mueller P. (2006). Exploring the knowledge filter: How entrepreneurship and university-industry relationships drive economic growth, Research Policy, 35, 1499-1508.

Ou Yang, H., and Hwang, J.-T. (2006). International Trade Theory and Policy. Taiwan: San Min Books. (in Chinese)

Posner, M.V. (1961). International Trade and Technical Change. Oxford Economic Papers, 13, pp. 323-341.

Pottelsberghe, B.P., and Lichtenberg, F. (2001). Does Foreign Direct Investment Transfer Technology across Borders? Review of Economics and Statistics, 83, pp. 490-497.

Romer, P.M. (1986). Increasing Returns and Long-Run Growth, Journal of Political Economy, 94, 1002-1037.

Roper, S., and Love, J.H. (2002). Innovation and Export Performance: Evidence from the UK and German Manufacturing Plants. Research Policy, 31, pp. 1087-1102.

Roper, S., Love, J.H., and Hígon, D.A. (2006). The Determinants of Export Performance: Evidence for Manufacturing Plants in Ireland and Northern Ireland. Scottish Journal of Political Economy, 53, pp. 586-615.

Salomon, R.M., and Shaver, J.M. (2005). Innovation, Learning by Exporting: New Insights from Examining Firms. Journal of Economics \& Management Strategy, 14, pp. 431-460.

Salvatore, D. (2009). International Economics. New York: Wiley.

Tomiura, E. (2007). Effects of R\&D and Networking on the Export Decision of Japanese Firms. Research Policy, 36, pp. 758-767.

Tsou, M.-W., and Liu, J.-T. (1997). The Spillover Effect from Foreign Direct Investment: Empirical Evidence from Taiwan Manufacturing Industries. Taiwan Economic Review, 25(2), pp.155-181. (in Chinese)

UNCTAD (2007). World Investment Report: Transnational Corporations, Extractive Industries and Development. New York and Geneva: United Nations.

Vernon, R. (1966). International Investment and International Trade in the Product Cycle. Quarterly Journal of Economics, 80, pp. 190-207.

World Bank (2010), Country Classification by Income, accessed at http://data.worldbank.org/about/country-classifications/country-and-lending-groups.

Yang, C.H., Chen, J.R., and Chuang, W.B. (2004). Technology and Export Decisions. Small Business Economics, 22, pp. 349-364. 
Chang et al., Globalization and knowledge spillover: International direct investment, exports and patents

TABLES

Table 1. Time lags of R\&D

\begin{tabular}{|c|c|c|c|c|c|c|c|c|}
\hline \multirow{2}{*}{$\begin{array}{c}\text { TRI } \\
\text { PATENT }\end{array}$} & \multicolumn{4}{|c|}{ Fixed Effects } & \multicolumn{4}{|c|}{ Random Effects } \\
\hline & (1) & (2) & (3) & (4) & (5) & (6) & (7) & (8) \\
\hline EXP & $\begin{array}{c}1.604 \\
(2.77)^{* * *} \\
{[9.07]^{* * *}}\end{array}$ & $\begin{array}{c}1.526 \\
(3.02)^{* * *} \\
{[8.57]^{* * *}}\end{array}$ & $\begin{array}{c}1.423 \\
(1.98)^{* *} \\
{[7.85]^{* * *}}\end{array}$ & $\begin{array}{c}1.245 \\
(1.76)^{*} \\
{[6.44]^{* * *}}\end{array}$ & $\begin{array}{c}1.553 \\
(2.99)^{* * *} \\
{[8.73]^{* * *}}\end{array}$ & $\begin{array}{c}1.476 \\
(3.02)^{* * *} \\
{[8.24]^{* * *}}\end{array}$ & $\begin{array}{c}1.375 \\
(1.92)^{*} \\
{[7.55]^{* * *}}\end{array}$ & $\begin{array}{c}1.197 \\
(1.81)^{*} \\
{[6.16]^{* * *}}\end{array}$ \\
\hline ODI & $\begin{array}{c}1.404 \\
(2.93)^{* *} \\
* \\
{[2.95]^{* *}} \\
*\end{array}$ & $\begin{array}{c}1.377 \\
(2.99)^{* *} \\
* \\
{[3.01]^{* *}} \\
*\end{array}$ & $\begin{array}{c}1.175 \\
(2.57)^{* *} \\
* \\
{[2.61]^{* *}} \\
*\end{array}$ & $\begin{array}{c}1.018 \\
(2.22)^{* *} \\
{[2.30]^{* *}}\end{array}$ & $\begin{array}{c}1.427 \\
(2.91)^{* * *} \\
{[2.99]^{* * *}}\end{array}$ & $\begin{array}{c}1.411 \\
(3.03)^{* * *} \\
{[3.08]^{* * *}}\end{array}$ & $\begin{array}{c}1.207 \\
(2.55)^{* *} \\
{[2.68]^{* * *}}\end{array}$ & $\begin{array}{c}1.049 \\
(2.29)^{* *} \\
{[2.37]^{* *}}\end{array}$ \\
\hline IDI & $\begin{array}{c}-0.912 \\
(-1.21) \\
{[-1.92]^{*}}\end{array}$ & $\begin{array}{c}-0.859 \\
(-1.60) \\
{[-1.89]^{*}}\end{array}$ & $\begin{array}{c}-0.724 \\
(-1.42) \\
{[-1.65]^{*}}\end{array}$ & $\begin{array}{l}-0.646 \\
(-1.43) \\
{[-1.49]}\end{array}$ & $\begin{array}{c}-0.938 \\
(-1.26) \\
{[-1.96]^{* *}}\end{array}$ & $\begin{array}{c}-0.883 \\
(-1.62) \\
{[-1.93]^{*}}\end{array}$ & $\begin{array}{c}-0.735 \\
(-1.44) \\
{[-1.66]^{*}}\end{array}$ & $\begin{array}{l}-0.650 \\
(-1.44) \\
{[-1.49]}\end{array}$ \\
\hline L0_GERD & $\begin{array}{c}11.837 \\
(1.33) \\
{[3.83]^{* *}} \\
*\end{array}$ & & & & $\begin{array}{c}12.648 \\
(1.47) \\
{[4.13]^{* *}} \\
*\end{array}$ & & & \\
\hline L1_GERD & & $\begin{array}{c}9.577 \\
(1.56) \\
{[3.15]^{* *}} \\
*\end{array}$ & & & & $\begin{array}{c}10.364 \\
(1.68)^{*} \\
{[3.45]^{* *}} \\
*\end{array}$ & & \\
\hline L2_GERD & & & $\begin{array}{c}6.647 \\
(1.08) \\
{[2.21]^{* *}}\end{array}$ & & & & $\begin{array}{c}7.383 \\
(1.17) \\
{[2.48]^{* *}}\end{array}$ & \\
\hline L3_GERD & & & & $\begin{array}{c}5.346 \\
(0.97) \\
{[1.78]^{*}}\end{array}$ & & & & $\begin{array}{c}6.024 \\
(0.96) \\
{[2.03]^{* *}}\end{array}$ \\
\hline CONSTANTS & $\begin{array}{c}1.608 \\
(2.73)^{* * *} \\
{[14.27]^{* * *}}\end{array}$ & $\begin{array}{c}1.848 \\
(2.61)^{* * *} \\
{[15.85]^{* * *}}\end{array}$ & $\begin{array}{c}2.092 \\
(2.35)^{* *} \\
{[17.31]^{* * *}}\end{array}$ & $\begin{array}{c}2.347 \\
(1.90)^{*} \\
{[18.13]^{* *}} \\
*\end{array}$ & $\begin{array}{c}1.605 \\
(2.72)^{* * *} \\
{[14.23]^{* * *}}\end{array}$ & $\begin{array}{c}1.845 \\
(2.62)^{* * *} \\
{[15.80]^{* * *}}\end{array}$ & $\begin{array}{c}2.089 \\
(2.29)^{* *} \\
{[17.26]^{* *}} \\
*\end{array}$ & $\begin{array}{c}2.346 \\
(1.98)^{* *} \\
{[18.08]^{* *}} \\
*\end{array}$ \\
\hline $\begin{array}{l}\text { Log } \\
\text { likelihood } \\
\text { Wald chi2 }\end{array}$ & $\begin{array}{c}-1967.3 \\
35.10\end{array}$ & $\begin{array}{c}-1770.0 \\
24.66\end{array}$ & $\begin{array}{c}-1578.2 \\
9.95\end{array}$ & $\begin{array}{c}-1387.3 \\
9.19\end{array}$ & $\begin{array}{c}-2316.9 \\
34.87\end{array}$ & $\begin{array}{c}-2117.5 \\
23.14\end{array}$ & $\begin{array}{c}-1923.5 \\
10.05\end{array}$ & $\begin{array}{c}-1729.6 \\
8.91\end{array}$ \\
\hline Prob > chi 2 & 0.000 & 0.000 & 0.041 & 0.057 & 0.000 & 0.000 & 0.040 & 0.063 \\
\hline $\begin{array}{l}\text { Groups } \\
\text { Observation } \\
\mathrm{S}\end{array}$ & $\begin{array}{c}37 \\
440\end{array}$ & $\begin{array}{c}37 \\
403\end{array}$ & $\begin{array}{c}37 \\
366\end{array}$ & $\begin{array}{c}37 \\
329\end{array}$ & $\begin{array}{c}37 \\
440\end{array}$ & $\begin{array}{c}37 \\
403\end{array}$ & $\begin{array}{c}37 \\
366\end{array}$ & $\begin{array}{c}37 \\
329\end{array}$ \\
\hline
\end{tabular}

Note: Bootstrap $t$-statistics are in parentheses, and $t$-statistics without bootstrapping are in brackets. $* * *, * *$ and $*$ denote significance at the $1 \%, 5 \%$ and $10 \%$ levels, respectively. 
Chang et al., Globalization and knowledge spillover: International direct investment, exports and patents

Table 2. Basic model

\begin{tabular}{l|cc}
\hline TRI_PATENT & Fixed Effects & Random Effects \\
\hline \multirow{2}{*}{ EXP } & 1.526 & 1.476 \\
& $(3.02)^{* * *}$ & $(3.02)^{* * *}$ \\
& {$[8.57]^{* * *}$} & {$[8.24]^{* * *}$} \\
ODI & 1.377 & 1.411 \\
& $(2.99)^{* * *}$ & $(3.03)^{* * *}$ \\
& {$[3.01]^{* * *}$} & {$[3.08]^{* * *}$} \\
IDI & -0.859 & -0.883 \\
& $(-1.60)$ & $(-1.62)$ \\
& {$[-1.89]^{*}$} & {$[-1.93]^{*}$} \\
L1_GERD & 9.577 & 10.364 \\
& $(1.56)$ & $(1.68)^{*}$ \\
& {$[3.15]^{* * *}$} & {$[3.45]^{* * *}$} \\
CONSTANTS & 1.848 & 1.845 \\
& $(2.61)^{* * *}$ & $(2.62)$ \\
& {$[15.85]^{* * *}$} & {$[15.80]^{* * *}$} \\
\hline Log likelihood & -1769.9537 & -2117.5386 \\
Wald chi2 & 24.66 & 23.14 \\
Prob $>$ chi2 & 0.000 & 0.000 \\
\hline Groups & 37 & 37 \\
Observations & 403 & 403 \\
\hline Hausman test & & -0.36 \\
\hline
\end{tabular}

Note: Bootstrap $t$-statistics are in parentheses, and $t$-statistics without bootstrapping are in brackets. ${ }^{* * *},{ }^{* *}$ and $*$ denote significance at the $1 \%, 5 \%$ and $10 \%$ levels, respectively. 
Chang et al., Globalization and knowledge spillover: International direct investment, exports and patents

Table 3. Model with decomposition of IDI

\begin{tabular}{l|cc}
\hline TRI_PATENT & Fixed Effects & Random Effects \\
\hline \multirow{3}{*}{ EXP } & 1.489 & 1.438 \\
& {$[3.08)^{* * *}$} & $(2.92)^{* * *}$ \\
& {$[8.28]^{* * *}$} & {$[7.94]^{* * *}$} \\
\hline \multirow{3}{*}{ ODI } & 1.255 & 1.286 \\
& $(2.91)^{* * *}$ & {$[3.05)^{* * *}$} \\
M\&A_SALE & {$[2.73]^{* * *}$} & {$[2.80]^{* * *}$} \\
& 0.267 & 0.290 \\
& $(0.51)$ & $(0.52)$ \\
PRIVATE & {$[0.37]$} & {$[0.40]$} \\
& -1.297 & -1.346 \\
& {$[-1.81)^{*}$} & $(-1.76)^{*}$ \\
L1_GERD & {$[-2.56]^{* * *}$} & {$[-2.64]^{* * *}$} \\
& 9.457 & 10.244 \\
& $(1.54)$ & $(1.66)^{*}$ \\
CONSTANTS & {$[3.10]^{* * *}$} & {$[3.40]^{* * *}$} \\
& 1.858 & 1.855 \\
& $(2.65)^{* * *}$ & $(2.71)^{* * *}$ \\
\hline Log likelihood & {$[15.87]^{* * *}$} & {$[15.81]^{* * *}$} \\
Wald chi2 & -1768.2 & -2115.6 \\
Prob>chi2 & 26.86 & 26.10 \\
\hline Groups & 0.000 & 0.000 \\
Observations & 37 & 37 \\
\hline & 403 & 403 \\
\hline
\end{tabular}

Note: Bootstrap $t$-statistics are in parentheses, and $t$-statistics without bootstrapping are in brackets. $* * *, * *$ and $*$ denote significance at the $1 \%, 5 \%$ and $10 \%$ levels, respectively. 
Chang et al., Globalization and knowledge spillover: International direct investment, exports and patents

Table 4. Effects of using different R\&D data

\begin{tabular}{|c|c|c|c|c|}
\hline TRI_PATENT & $\begin{array}{c}\text { Fixed Effects } \\
\text { (1) }\end{array}$ & $\begin{array}{l}\text { Random Effects } \\
\text { (2) }\end{array}$ & $\begin{array}{l}\text { Fixed Effects } \\
\text { (3) }\end{array}$ & $\begin{array}{c}\text { Random Effects } \\
\text { (4) }\end{array}$ \\
\hline EXP & $\begin{array}{c}1.489 \\
(3.08)^{* * *} \\
{[8.28]^{* * *}}\end{array}$ & $\begin{array}{c}1.438 \\
(2.92)^{* * *} \\
{[7.94]^{* * *}}\end{array}$ & $\begin{array}{c}1.431 \\
(3.03)^{* * *} \\
{[7.83]^{* * *}}\end{array}$ & $\begin{array}{c}1.379 \\
(3.08)^{* * *} \\
{[7.48]^{* * *}}\end{array}$ \\
\hline ODI & $\begin{array}{c}1.255 \\
(2.91)^{* * *} \\
{[2.73]^{* * *}}\end{array}$ & $\begin{array}{c}1.286 \\
(3.05)^{* * *} \\
{[2.80]^{* * *}}\end{array}$ & $\begin{array}{c}1.217 \\
(3.09)^{* * *} \\
{[2.68]^{* * *}}\end{array}$ & $\begin{array}{c}1.244 \\
(2.91)^{* * *} \\
{[2.74]^{* * *}}\end{array}$ \\
\hline M\&A_SALE & $\begin{array}{c}.267 \\
(0.51) \\
{[0.37]}\end{array}$ & $\begin{array}{c}.290 \\
(0.52) \\
{[0.40]}\end{array}$ & $\begin{array}{c}.209 \\
(0.39) \\
{[0.30]}\end{array}$ & $\begin{array}{c}.233 \\
(0.44) \\
{[0.33]}\end{array}$ \\
\hline PRIVATE & $\begin{array}{c}-1.297 \\
(-1.81)^{*} \\
{[-2.56]^{* * *}}\end{array}$ & $\begin{array}{c}-1.346 \\
(-1.76)^{*} \\
{[-2.64]^{* * *}}\end{array}$ & $\begin{array}{c}-1.249 \\
(-1.83)^{*} \\
{[-2.50]^{* *}}\end{array}$ & $\begin{array}{c}-1.294 \\
(-1.80)^{*} \\
{[-2.56]^{* * *}}\end{array}$ \\
\hline L1_GERD & $\begin{array}{c}9.457 \\
(1.54) \\
{[3.10]^{* * *}}\end{array}$ & $\begin{array}{c}10.244 \\
(1.66)^{*} \\
{[3.40]^{* * *}}\end{array}$ & & \\
\hline L1_BERD & & & $\begin{array}{c}14.295 \\
(1.39) \\
{[4.00]^{* * *}}\end{array}$ & $\begin{array}{c}15.235 \\
(1.61) \\
{[4.32]^{* * *}}\end{array}$ \\
\hline CONSTANTS & $\begin{array}{c}1.858 \\
(2.65)^{* * *} \\
{[15.87]^{* * *}}\end{array}$ & $\begin{array}{c}1.855 \\
(2.71)^{* * *} \\
{[15.81]^{* * *}}\end{array}$ & $\begin{array}{c}1.951 \\
(2.91)^{* * *} \\
{[17.12]^{* * *}}\end{array}$ & $\begin{array}{c}1.953 \\
(2.96)^{* * *} \\
{[17.10]^{* * *}}\end{array}$ \\
\hline Log likelihood & -1768.2 & -2115.6 & -1737.0 & -2083.9 \\
\hline $\begin{array}{l}\text { Wald chi2 } \\
\text { Prob > chi2 }\end{array}$ & $\begin{array}{l}26.86 \\
0.000\end{array}$ & $\begin{array}{l}26.10 \\
0.000\end{array}$ & $\begin{array}{l}29.60 \\
0.000\end{array}$ & $\begin{array}{l}26.17 \\
0.000\end{array}$ \\
\hline $\begin{array}{l}\text { Groups } \\
\text { Observations }\end{array}$ & $\begin{array}{c}37 \\
403\end{array}$ & $\begin{array}{c}37 \\
403\end{array}$ & $\begin{array}{c}37 \\
399\end{array}$ & $\begin{array}{c}37 \\
399\end{array}$ \\
\hline
\end{tabular}

Note: Bootstrap $t$-statistics are in parentheses, and $t$-statistics without bootstrapping are in brackets. $* * *$ and $*$ denote significance at the $1 \%$ and $10 \%$ levels, respectively. 